\title{
Türkiye Kıyılarında Deniz Suyu Sıcaklık Değişiminin CBS ile Analizi ve Ekolojik Etkilerinin Değerlendirilmesi
}

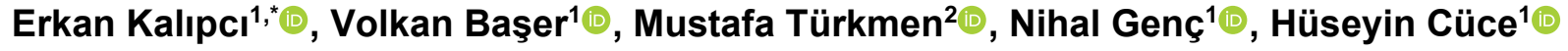 \\ ${ }^{1}$ Giresun Üniversitesi, Mühendislik Fakültesi, Harita Mühendisliği Bölümü, Giresun. \\ ${ }^{2}$ Giresun Üniversitesi, Fen Edebiyat Fakültesi, Biyoloji Bölümü, Giresun.
}

\section{Özet}

Deniz suyu sıcaklıklarındaki artış sucul canlılarda ekolojik problemlere yol açabilmektedir. Bu düşünceden hareketle yapılan çalışmada; Türkiye'nin kıylları boyunca yaşanan deniz suyu sıcaklığı artış oranları değişimi yıllık bazda irdelenerek, coğrafi bilgi sistemi ile değerlendirilmesi yapılmıştır. Araștırmada kullanılan veriler, Tarım ve Orman Bakanlı̆̆ Meteoroloji Genel Müdürlüğ̈̈nden temin edilmiştir. 1970- 2019 yılları arasında Karadeniz, Akdeniz, Ege ve Marmara denizi, deniz suyu sicaklık verileri irdelenmiş ve 50 yıllık analiz sonuçları ArcGIS ortamında işlenerek deniz suyu sıcaklıkları haritası oluşturulmuştur. Yapılan çalışma sonucunda; 1970 yılından 2000 yılına kadar ki süreçte deniz suyu sıcaklı̆̆ı ortalamalarının değișim trendinin birbirine yakın ortalamalarda devam ettiği, 2000-2010 yillar arasinda bir önceki dönem periyoduna (1990-1999) oranla Karadeniz'de 0,8² Akdeniz'de $0,5^{\circ} \mathrm{C}$, Marmara ve Ege denizlerinde $0,4^{\circ} \mathrm{C}^{\prime} e$ deniz suyu sicaklı̆̆ ortalamalarındaki yükselişin özellikle 2010-2019 döneminde belirginleştiği görülmüştür. 1970-1979 yılları ortalama deniz suyu sicakları ile 2010-2019 yılları ortalama deniz suyu sicakları karșılaștırıldığında; ortalama deniz suyu sicaklı̆̆ının Karadeniz ve Akdeniz de $1,2^{\circ} \mathrm{C}$, Ege denizinde $0,9^{\circ} \mathrm{C}$, Marmara denizinde ise $1,5^{\circ} \mathrm{C}$ arttı̆g gözlenmiştir. Deniz suyunda yaşanan bu sıcaklık artışının ekolojik dengeye olası etkileri tartışılmışıtır.

Anahtar Sözcükler

Coğrafi Bilgi Sistemi, Deniz Suyu Sicaklık Haritası, Sucul Canlılar, Türkiye

\section{Analysis of Sea Water Temperature Change on The Coast of Turkey with GIS and Evaluation of Its Ecological Effects}

\begin{abstract}
An increase in seawater temperatures can cause ecological problems in aquatic organisms. In the study based on this idea; Turkey's sea surface temperatures were examined on an annual basis and determined increase rate which are chancing along the coasts were evaluated with geographic information systems. The data used in the study were obtained from the Turkish State Meteorological Service of the Ministry of Agriculture and Forestry. Between 1970 and 2019, sea surface temperatures of the Black Sea, Mediterranean, Aegean, and Marmara were examined and the 50-year analysis results were processed in the ArcGIS environment and sea surface temperature maps were prepared along the Turkey's coasts. As a result of the work; sea surface temperatures averages were continued to increase as close to each other with changing trend in the period from 1970 to 2000, The sea surface temperatures were increased by $0.8^{\circ} \mathrm{C}$ in the Black Sea, $0.5^{\circ} \mathrm{C}$ in the Mediterranean, $0.4^{\circ} \mathrm{C}$ in the Marmara and the Aegean seas between the years 2000-2010, compared to the previous period (1990-1999). The increase in sea surface temperatures means were became evident especially in the 2010-2019 period. When the sea surface temperatures averages were compared between 1970-1979 and 2010-2019; It was observed that the sea surface temperatures averages were increased by $1.2{ }^{\circ} \mathrm{C}$ in the Black Sea and the Mediterranean, $0.9^{\circ} \mathrm{C}$ in the Aegean Sea, and $1.5^{\circ} \mathrm{C}$ in the Marmara Sea. The possible effects of this temperature increase in seawater on ecological balance were discussed.
\end{abstract}

$\underline{\text { Keywords }}$

Geographic Information System, Sea Surface Temperature Map, Aquatic Creatures, Turkey

\section{Giriş}

Endüstrileşme ile birlikte artan enerji ihtiyacının çoğunlukla fosil yakıt kaynaklarından elde edilmesi (Demirbaş ve Aydın 2020), atmosfere salınan sera gazlarını arttırmakta, hidrolojik döngüyü değiştirmekte ve doğa olaylarında sürekli uç değerlerin (rekorların) görülmesine sebep olmaktadır (Şişman 2019). Bu küresel değişimin ekosistem ve toplumda ortaya çıkardığı olumsuz etkiler dünyada endişe uyandırmaktadır (Hereher 2020; Li vd. 2019). 
Deniz suyu sıcaklıklarında görülen hızlı değişimler de bu endişelere bir örnektir. Deniz suyu sıcaklıkları yüzeyden dibe doğru azalmaktadır (Kocataş 2005). Deniz suyu yüzey sıcaklığının (DSYS) artması veya azalması denizlerdeki ekolojik dengeyi değiştirerek pek çok canlıyı etkileyebileceği gibi, bu değişim denizlerden ekonomik olarak yararlanan önemli bir kesimi de yakından ilgilendirir. Deniz ekosistemini direkt olarak etkileyen deniz suyu sıcaklığı, ayrıca iklimsel olayların oluşmasında da önemli faktörlerden birisidir. Ayrıca deniz suyu yüzey sıcaklığı hava ve deniz yüzeyleri arasındaki ısı değişiminin tahmin edilmesinde kullanılan önemli bir jeofiziksel parametredir. Yüzey suyu sıcaklı̆ı̆ındaki değişimler küresel iklim modelleri için gerekli olan, dünyanın 1S1 dengesinin ortaya konmasında ve atmosferik sirkülasyonların tayininde de oldukça önemlidir (Çakıroğlu 2019). Bu bağlamda deniz suyunun sıcaklığının artması, güneşten gelen ışınların absorbsiyonu, su altındaki oseanik kabuk sıcaklığının sulara iletilmesi, denizaltı volkanik faaliyetlerin etkisi ve med-cezir enerjisi ile yüzeyde esen rüzgârların oluşturduğu kinetik enerjinin 1sıya dönüştürülmesine bağlıdır. Diğer taraftan deniz suyu sıcaklığının azalması, atmosferin daha soğuk zamanlarında yüzey sularında oluşan buharlaşma olayına bağlı olarak değişmektedir (Kocataş 2005). Hükümetler arası İklim Değişikliği Paneli iklim değişikliği konusundaki çalışmalarda, deniz suyu sıcaklıklarının tanımlanmasının çevresel parametreler içerisinde en önemlilerinden biri olduğunu belirtmektedir (Houghton 1996).

Bozkurt ve Sen (2011)'in Türkiye'yi çevreleyen denizlerde yüzey suyu sıcaklık değişimlerinin Anadolu yarımadası yağışlarına etkisinin incelendiği çalışmada; normalden iki derece daha yüksek yaz ve sonbahar deniz suyu sıcaklıklarının, Anadolu yarımadasının farklı bölgelerinde sel ve taşkınlara yol açacak şekilde yağışları artırdığı belirtilmiştir. Bengil ve Mavruk (2018) tarafından Türkiye denizlerinde 1981-2014 yıllarını kapsayan dönemde deniz suyundaki ısınmanın etkilerinin çalışıldığı araştırmada, özellikle Karadeniz ve Marmara DSYS'nin Batı Ege ve Akdenizin Doğusuna göre daha fazla isındığı tespit edilmiștir. Diğer bir çalışmada, iklim değişikliğinin ortaya çıkaracağı olumsuzlukların veya firsatların değerlendirilebilmesi açısından, üç tarafı denizlerle çevrili olan Türkiye'de deniz suyu sıcaklık verilerinin detaylı şekilde analiz edilerek yorumlanmasının hidroloji, tarım, hayvancılık, meteoroloji, turizm vb. sektörler için çok önemli ve gerekli olup yağış, evapotranspirasyon, nem, rüzgâr hızı, sıcaklık verileri ile uğraşan hidroloji, hidrometeoroloji ve hidroklimatoloji alanlarına da önemli katkılar sağlayacağı ifade edilmiştir (Şişman 2019). Okyanusların 1sınması ve asiditesinin artması, sucul canlılarda kirleticilerin biyoakümülasyonu, besin zincirinin yapısı ve dağılımı üzerindeki etkileri, fiziksel, biyokimyasal ve sucul canlıların coğrafik dağılımı açısından daha fazla araştırma yapılmasını gerektirmektedir. İklim değişikliğinin gelecekte sucul canlılar üzerindeki etkisini inceleyen çok az araştırma mevcut olup, gelecekte sucul üretimin nasıl olacağı, besin tedarikinin hangi aşamada olacağı, sucul canlıların artan sıcaklık, toksik alg, $\mathrm{CO}_{2}$, hastalık, kirletici ve düşük oksijen ortamına vereceği tepkiler için çalışmalar yapılarak bir veritabanı oluşturulmalıdır (Kleypas vd. 2005). Bilgisayar destekli veri analizi ve görselleştirme araçları; su kaynaklarının korunması, geliştirilmesi ve yönetimi çalışmalarında önemli rol oynamaktadır. Özellikle Coğrafi Bilgi Sistemleri (CBS) bu amaçla son yıllarda dünya çapında oldukça yaygın olarak kullanılmakta olup, Türkiye'de su kalitesi ve kirliliği izleme çalışmalarında CBS yardımıyla analiz edilmiş mekânsal dağılım haritaları ortaya koyulmaya başlanmıştır (Girgin vd. 2004; Savci ve Bağdatlı 2015). Bu düşünceden hareketle üç tarafı denizlerle çevrili yaklaşık $8592 \mathrm{~km}$ kıyı şeridine sahip olan Türkiye'de (Baser ve Biyik 2019); Karadeniz, Akdeniz, Ege ve Marmara denizi kıyı boyunca deniz suyu sicaklıkları 1970-2019 yılları arasında meteorolojik yönden değerlendirilerek, ArcGIS'de deniz suyu sıcaklıkları haritası hazırlanmıştır. Bunun yanı sıra deniz suyu sıcaklık değişiminin ekolojik dengeye olası etkileri de tartışılmıştır.

\section{Materyal ve Yöntem}

1970-2019 yılları arasında Karadeniz, Marmara, Ege ve Akdeniz Kıyı sularında ölçülmüş 50 yıllık ortalama deniz suyu sıcaklık verileri, T.C. Tarım ve Orman Bakanlı̆̆ı, Meteoroloji Genel Müdürlüğünden temin edilerek çalışma kapsamında kullanılmıştır (MGM 2020). Deniz suyu sıcaklık ölçüm istasyonlarını gösterir harita Şekil 1'de verilmiştir (MGM 2021). 10'ar yıllık olmak üzere 5 periyodik döneme ayrılmış olan deniz suyu sıcaklıklarının modellenebilmesi amacıyla sayısallaştırma yapılarak vektör veri oluşturulmuştur. Vektör veri ArcGIS ortamına aktarılmış, ardından 50 yıllık ortalama deniz suyu sıcaklıkları tablolar haline getirilerek her bir sıcaklığı ilgili olduğu denizle eşleş̧irmek üzere vektör verinin öznitelik tablosuyla ilişkilendirilmiştir. Daha sonra deniz suyu sıcaklıklarının dönemlere bağlı olarak tematik haritalanması sağlanmıştır. Böylelikle Ege, Akdeniz, Karadeniz ve Marmara denizlerine ait ortalama deniz suyu sıcaklık dağılım haritaları oluşturulmuştur. Tüm istasyonlardan son 50 yılı yansıtan ve hem dönemsel hem de aylık bazda deniz suyundaki sıcaklık değişimi grafiksel analizlerle incelenmiş, tematik haritalar ile görsel bir değerlendirmeye imkan sağlanmıştır. Elde edilen sonuçlar, iklim değişimine bağlı olarak sürekli bir değişim gösteren ülkemiz deniz sularındaki sıcaklık artış trendinin yönelimi, hızı, deniz ekolojisine ve deniz çevresindeki sosyal hayata olası etkileri çerçevesinde tartı̧ıılmıştır. 


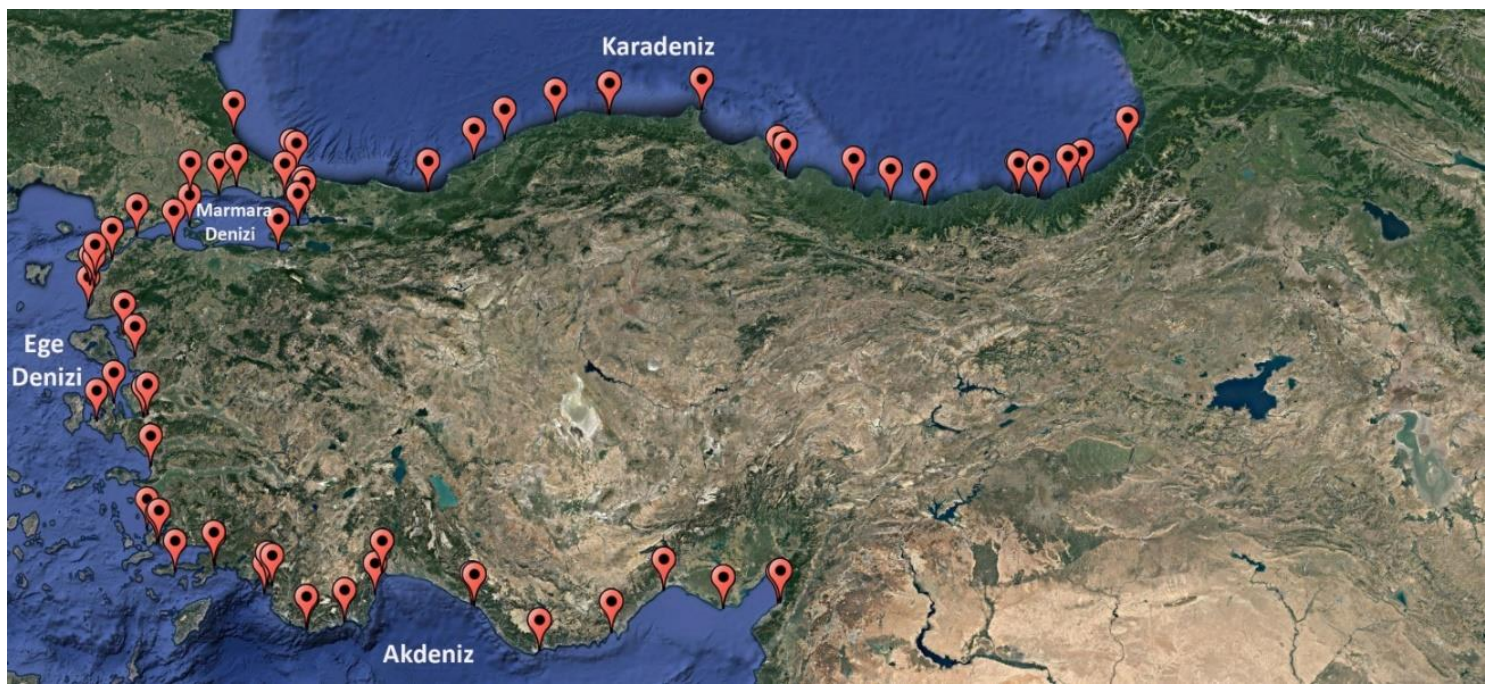

Şekil 1: Meteoroloji Genel Müdürlüğü deniz suyu sıcaklığı ölçüm istasyonları (MGM 2021 'den adapte edilmiştir.)

\section{Bulgular ve Tartışma}

\subsection{Karadeniz Deniz Suyu Sıcaklığı}

1970-2019 yılları arasında Karadeniz'de en sıcak deniz suyunun 2019 yılında 18,5 C derece görüldüğü, en soğuk deniz suyu sıcaklığının ise 1987 yılında $13,8^{\circ} \mathrm{C}$ derece olduğu belirlenmiştir. Karadenizde 1970-2019 yılları arasında yıllık ortalama deniz suyu sıcaklık verisinin dağılımı ve eğilimi Şekil 2'de verilmiştir. Karadenizde 2018 ve 2019 yıllarına ait aylık değerleri ile 1970-2019 yıllarına ait uzun yıllar aylık ortalama deniz suyu sıcaklık değerlerinin karşılaştırılması ise Şekil 3'de verilmiştir (MGM 2020). Şekil 2 ve Şekil 3 incelendiğinde, Karadeniz aylık ortalama deniz suyu sıcaklığg artışının 1970-2019 yılları arasındaki ortalamalara kıyasla 2018 yılında artış gösterdiği özellikle de 2019 yılında sıcaklık artışının elli yıllık kayıt göz önünde bulundurulduğunda en yüksek seviyede gerçekleştiği görülmektedir.

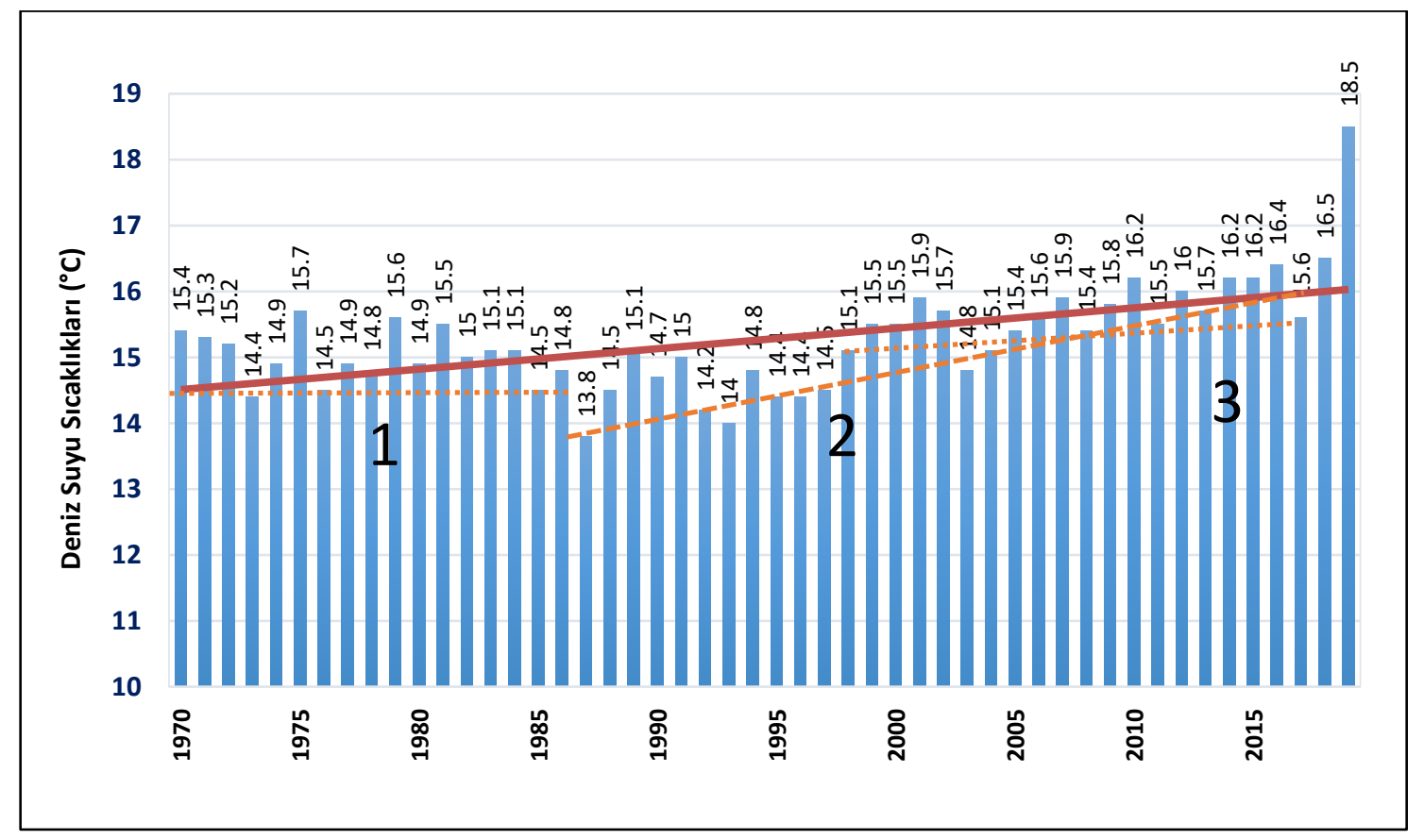

Şekil 2: Karadeniz deniz suyu sıcaklık verisinin 1970-2019 yılları arasındaki dağılımı ve eğilimi (MGM 2020) 


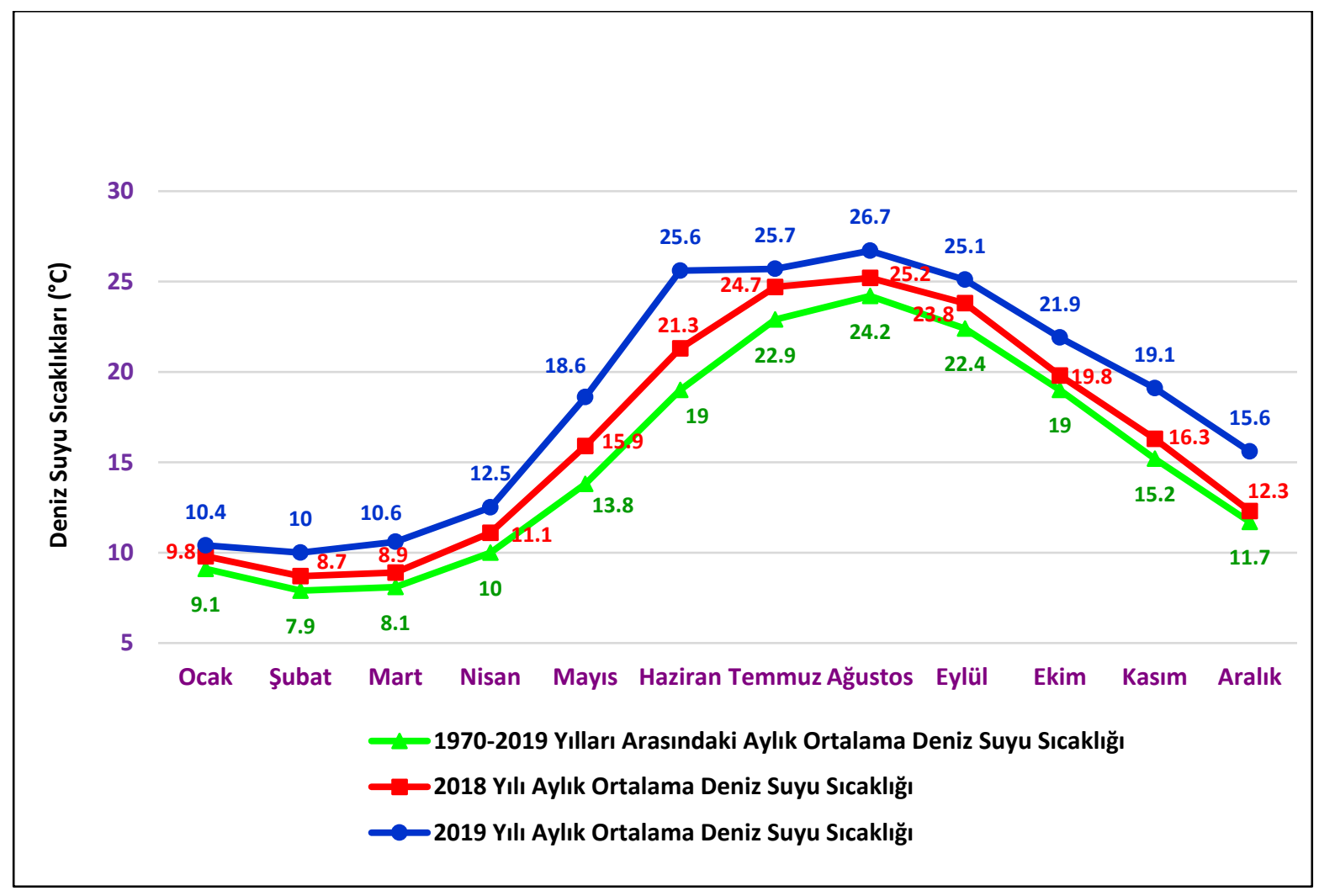

Şekil 3: Karadeniz 2018 ve 2019 yıllarına ait aylık değerleri ile 1970-2019 yıllarına ait uzun yıllar aylık ortalama deniz suyu sıcaklık değerleriyle karşılaştırılması (MGM 2020)

\subsection{Akdeniz Deniz Suyu Sıcaklığı}

Akdeniz'de 1970-2019 yılları arası deniz suyu sıcaklıkları incelendiğinde, deniz suyunun en sıcak olduğu derecenin 2019 yılında $23,8^{\circ} \mathrm{C}$ olduğu, en soğuk deniz suyu sıcaklığının ise 1992 yılında $20,6^{\circ} \mathrm{C}$ olduğu belirlenmiştir. 1970 2019 yılları arasında aylık ortalama deniz suyu sıcaklık verisinin dağılımı ve eğilimi Şekil 4'de verilmiştir. 1970-2019 yılları aylık ortalama deniz suyu sıcaklık değerlerinin 2018 ve 2019 yılları aylık değerleriyle karşılaştırılması ise Şekil 5'de verilmiştir. 1970-2017 yılları arası deniz suyu sıcaklıklarına $\left(21,4{ }^{\circ} \mathrm{C}\right)$ göre, 2017 yılı $\left(22,3^{\circ} \mathrm{C}\right)$ artışı $0,9^{\circ} \mathrm{C}$ ve 1970- 2018 yılları arasına $\left(21,4^{\circ} \mathrm{C}\right)$ göre 2018 yılı $\left(22,4^{\circ} \mathrm{C}\right) \operatorname{artış1~} 1,0^{\circ} \mathrm{C}$ 'dir (MGM 2020).

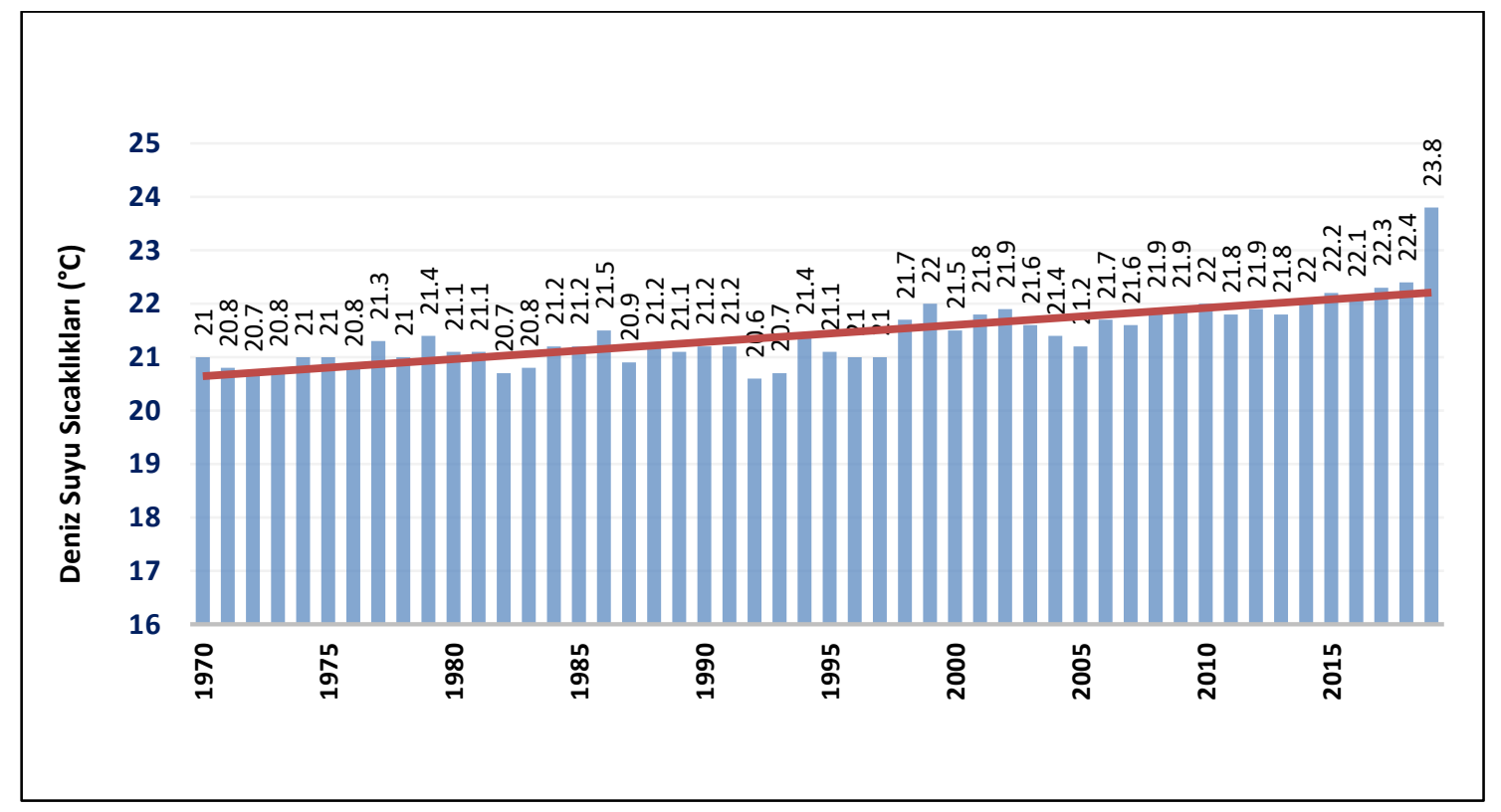

Şekil 4: Akdeniz deniz suyu sıcaklık verisinin 1970-2019 yılları arasındaki dağılımı ve eğilimi (MGM 2020) 
Şekil 4 ve Şekil 5' de görüldüğü üzere, Akdeniz aylık ortalama deniz suyu sıcaklığı artışının 1970-2019 yılları ortalama değerlerine göre 2018 yılında artış gösterdiği ve 2019 yılında su sıcaklığındaki ısınmanın daha da arttığı görülmektedir.

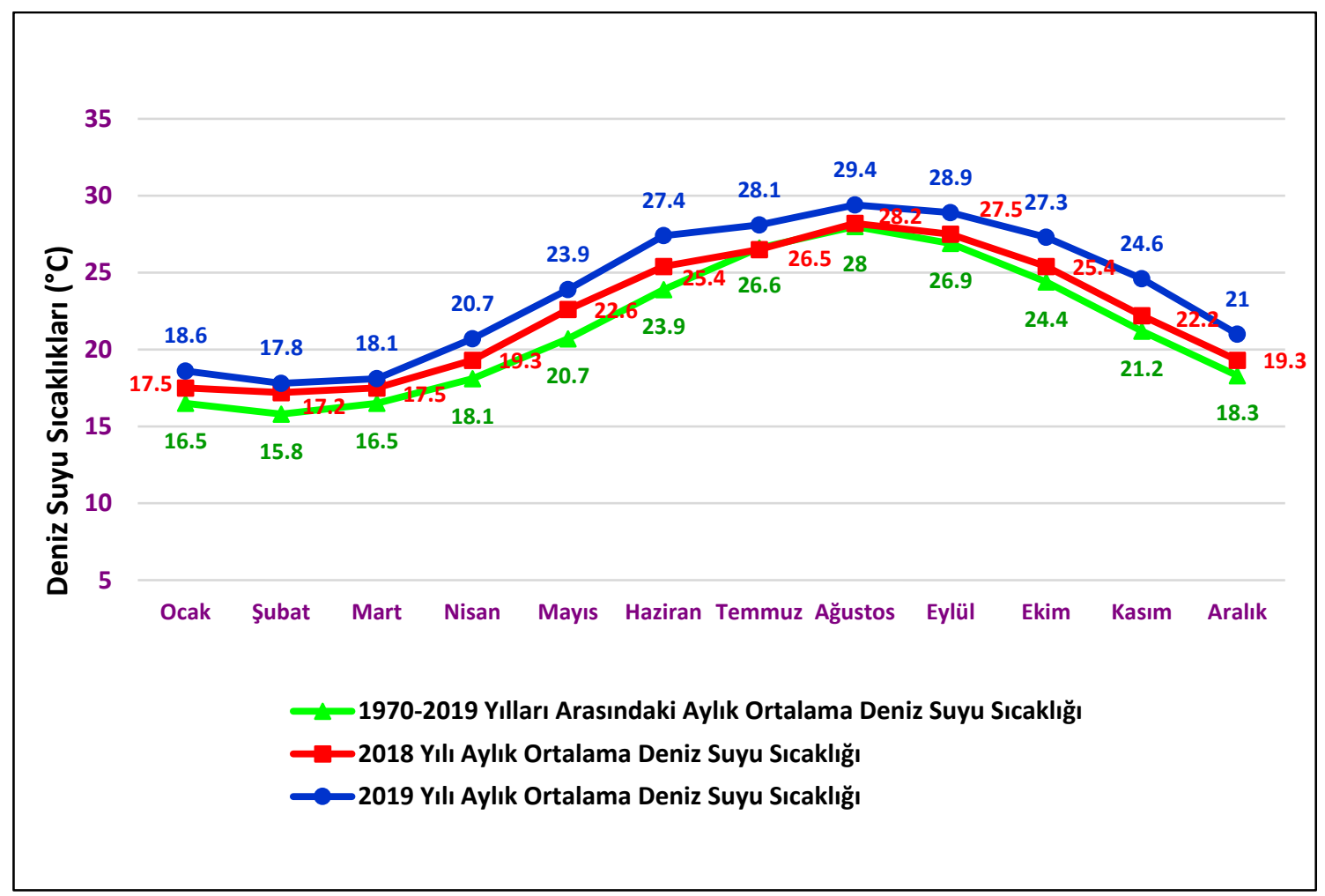

Şekil 5: Akdeniz 1970-2019 yılları aylık ortalama deniz suyu sıcaklık değerlerinin 2018 yılı ve 2019 yılı aylık değerleriyle karşılaştırılması (MGM 2020)

\subsection{Ege Denizi Deniz Suyu Sıcaklığı}

Ege denizinde 1970-2019 yılları arasında en sıcak deniz suyunun 2018 yılında $19.8^{\circ} \mathrm{C}$ derece görüldüğü, en soğuk deniz suyu sıcaklığının ise 1983 yılında $17.7^{\circ} \mathrm{C}$ derece olduğu belirlenmiştir. Ege denizinde 1970-2019 yılları arasında aylık ortalama deniz suyu sıcaklık verisinin dağılımı ve eğilimi Şekil 6' da verilmiştir. Ege denizine ait 1970-2019 yılları aylık ortalama deniz suyu sıcaklık değerlerinin 2018 ve 2019 yılları aylık değerleriyle karşılaştırılması ise Şekil 7'de verilmiştir (MGM 2020). Ege denizinde aylık ortalama deniz suyu sıcaklığı artışı incelendiğinde; 1970-2019 y1lları ortalama verilerine göre 2018 yılında artış gösterdiği, 2019 yılında ise deniz suyu sıcaklığındaki artışının daha da yükseldiği görülmektedir (Şekil 6 ve Şekil 7). 


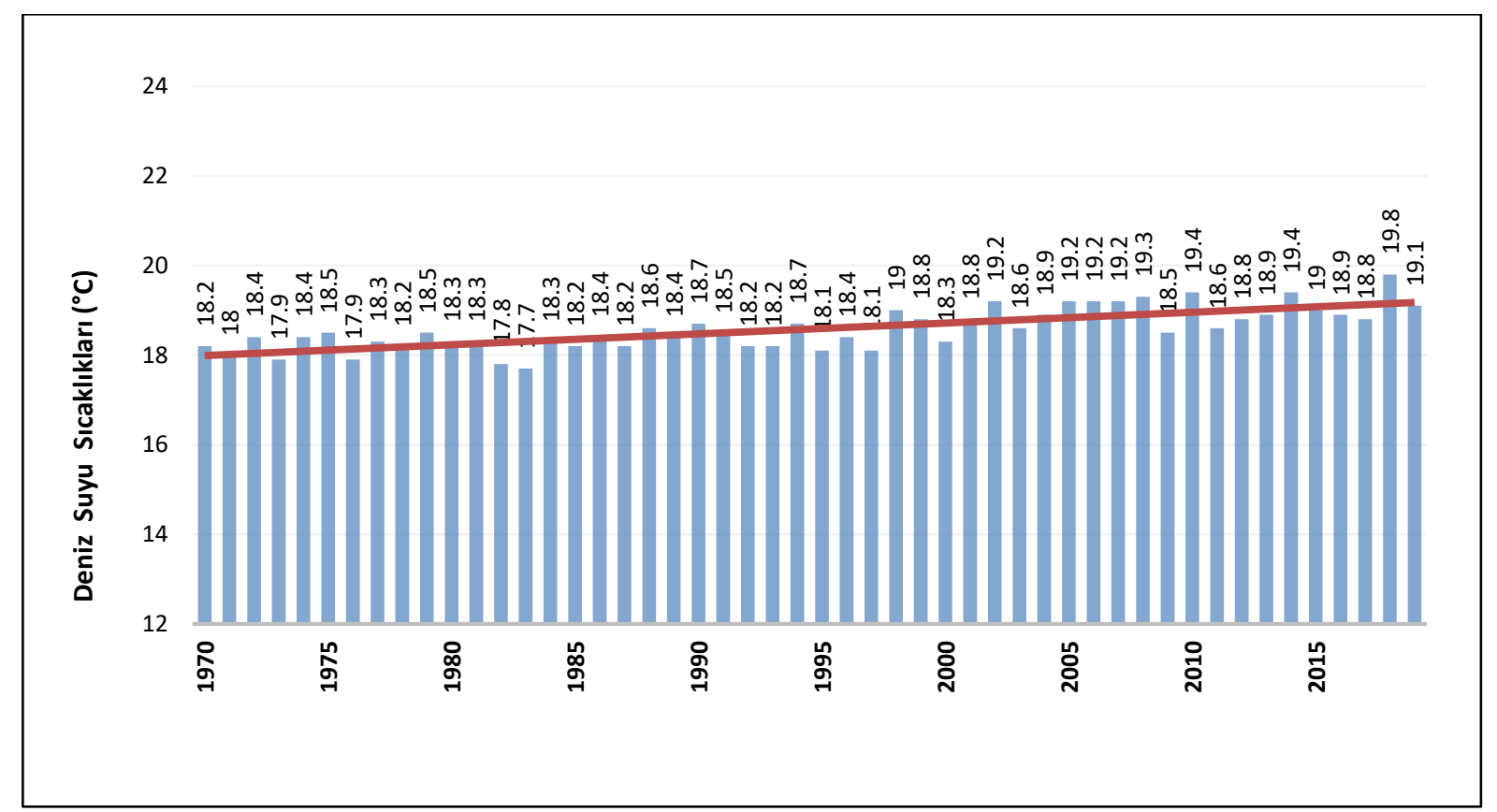

Şekil 6: Ege Denizi deniz suyu sıcaklık verisinin 1970-2019 yılları arasındaki dağılımı ve eğilimi (MGM 2020)

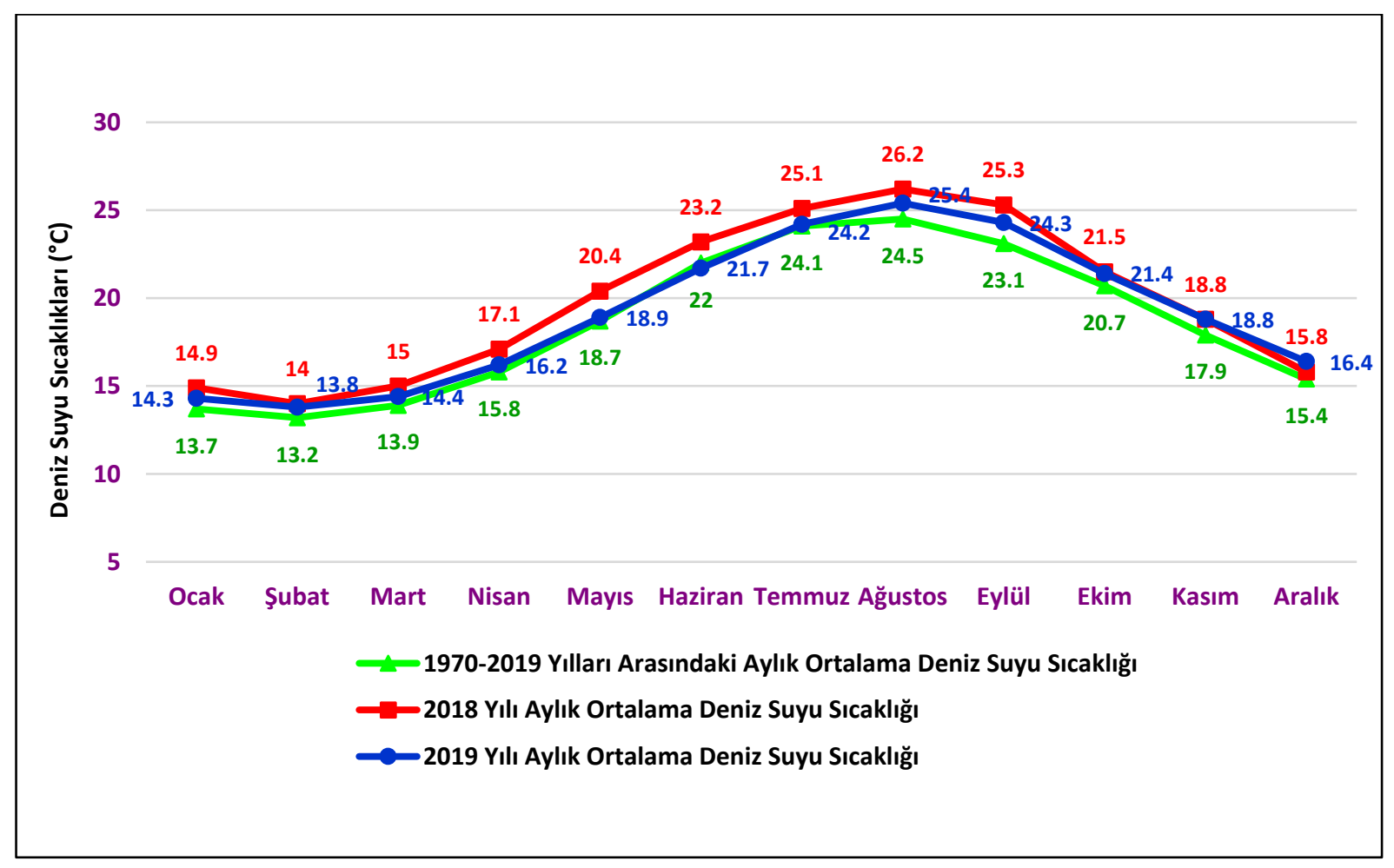

Şekil 7: Ege Denizi 1970-2019 yılları aylık ortalama deniz suyu sıcaklık değerlerinin 2018 yılı ve 2019 yılı aylık değerleriyle karşılaştırılması (MGM 2020)

\subsection{Marmara Denizi Deniz Suyu Sıcaklığı}

1970-2019 yılları arasında Marmara denizinde en sıcak deniz suyunun 2019 yılında $18,6^{\circ} \mathrm{C}$ derece görüldüğ̈̈, en soğuk deniz suyu sıcaklığının ise 1987 yılında $14,4^{\circ} \mathrm{C}$ derece olduğu tespit edilmiştir. Marmara denizinde 1970-2019 yılları arasında aylık ortalama deniz suyu sıcaklık verisinin dağılımı ve eğilimi Şekil 8'de yer almaktadır. Marmara denizinde 1970-2019 yılları aylık ortalama deniz suyu sıcaklık değerlerinin 2018 ve 2019 yılları aylık değerleri ile karşılaştırılması ise Şekil 9'da verilmiştir (MGM 2020). 
Şekil 8 ve Şekil 9 incelendiğinde, Marmara denizi aylık ortalama deniz suyu sıcaklığı ile 1970-2019 yılları arasındaki ortalamalar karşılaştırıldığında 2018 yılında deniz suyu sıcaklığının yükseldiği ve 2019 yılında bu yükselişin MartAralık ayları arasında daha da arttığı görülmektedir.

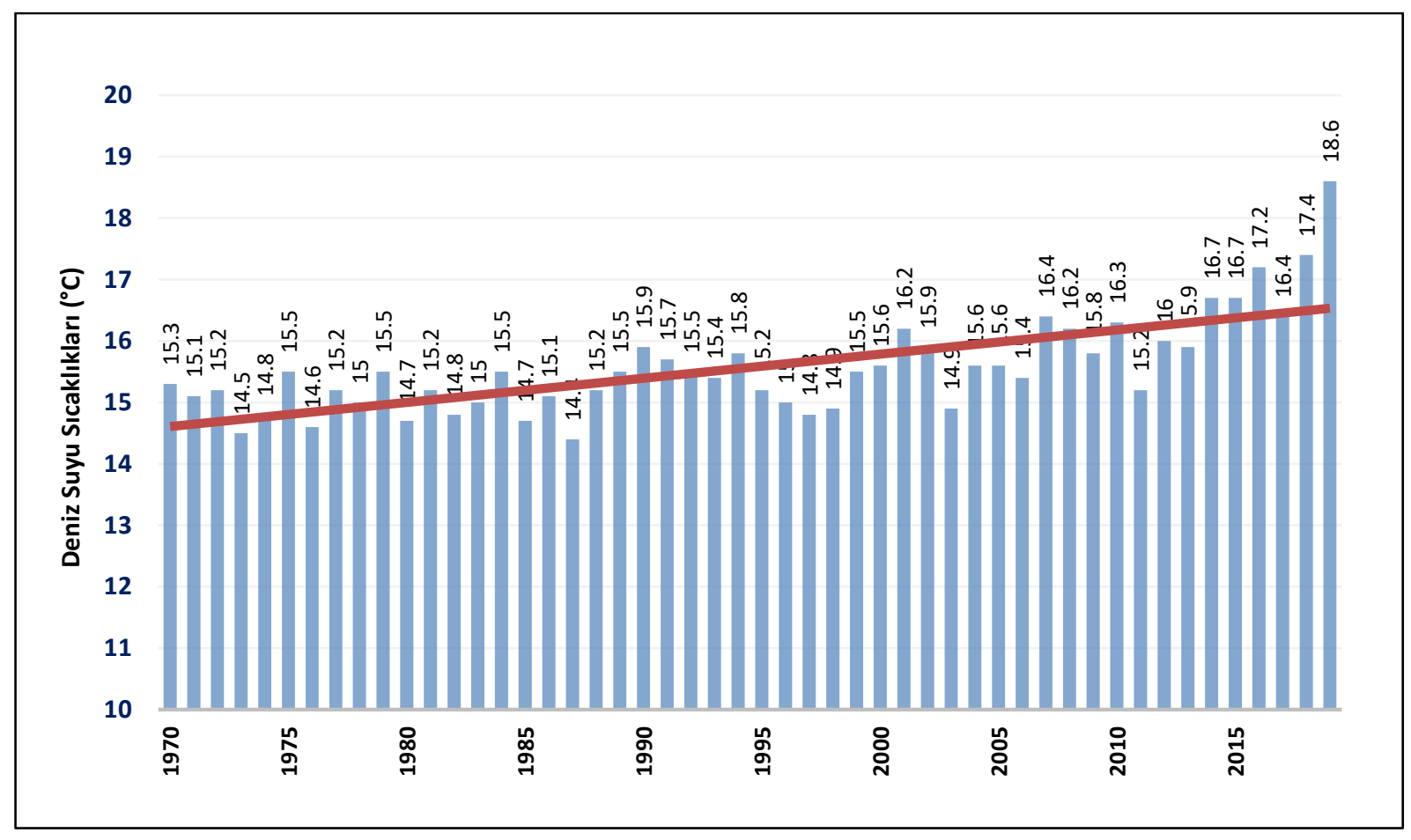

Şekil 8: Marmara Denizi deniz suyu sıcaklık verisinin 1970-2019 yılları arasındaki dağılımı ve eğilimi (MGM 2020)

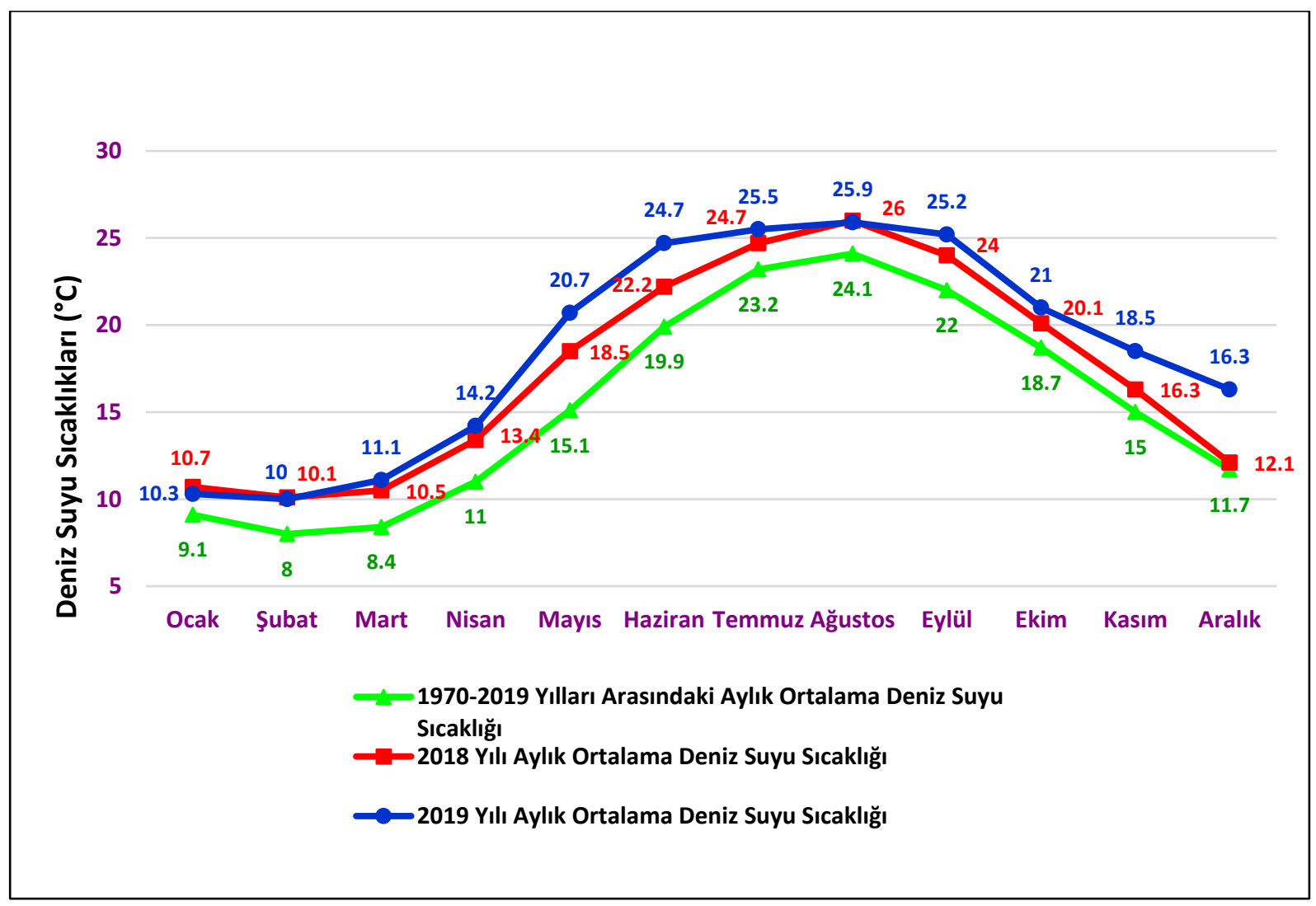

Şekil 9: Marmara Denizi 1970-2019 yılları aylık ortalama deniz suyu sıcaklık değerlerinin 2018 yılı ve 2019 yılı aylık değerleriyle karşılaştırılması (MGM 2020). 
Türkiye'ye kıyısı olan denizlerin 1970-2019 yılları arasındaki aylara (Ocak-Aralık) göre ortalama deniz suyu sıcaklıkları incelendiğinde; Karadeniz, Akdeniz, Ege ve Marmara denizlerinde kıyı boyunca sıcaklığın en düşük olduğu ay Şubat ayı iken en yüksek sıcaklık ise Ağustos ayında kaydedilmiştir. Türkiye karasularındaki denizlerimizde kıyı boyunca Şubat ayında gerçekleşmiş en düşük sıcaklık 2018 ve 2019'da, Karadeniz'de 8,7 ve 10,0, Akdeniz'de 17,2 ve 17,8, Ege Denizi'nde 14,0 ve 13,8, Marmara Denizi'nde 10,1 ve 10,0 ${ }^{\circ} \mathrm{C}$ 'dir (Şekil 1-Şekil 9). Türkiye karasularında Ağustos ayında gerçekleşmiş en yüksek sicaklık 2018 ve 2019'da sırasıyla, Karadeniz'de 25,2 ve 26,7, Akdeniz'de 28,2 ve 29,4, Ege Denizi'nde 26,2 ve 25,4, Marmara Denizi'nde 26,0 ve 25,9 ${ }^{\circ} \mathrm{C}$ 'dir (Şekil 1-Şekil 9). 50 yıllık dönem için ortalama deniz suyu sıcaklık verileri, 10' ar yıllık olmak üzere 5 periyotta değerlendirilmiş ve buna göre oluşturulan Karadeniz, Akdeniz, Ege ve Marmara kıyıları deniz suyu sıcaklık haritaları ise Şekil 10'da sunulmuştur. Şekil 10'da görüldüğü üzere; 1970 yılından 2000 yılına kadar deniz suyu sıcaklığı ortalamalarının değişim trendinin birbirine yakın ortalamalarda devam ettiği görülmektedir. 2000-2010 yılları arasında bir önceki dönem periyoduna (1990-1999) oranla Karadeniz'de $0,8^{\circ} \mathrm{C}$, Akdeniz'de $0,5^{\circ} \mathrm{C}$, Marmara ve Ege denizlerinde $0,4^{\circ} \mathrm{C}$ deniz suyu sicaklığ 1 artışı gözlenmiştir (Tablo 1).

Tablo 1: Deniz suyu ortalama sıcaklık değişimleri (MGM 2020)

\begin{tabular}{cccccc}
\hline Denizler & $\begin{array}{c}\mathbf{1 9 7 0 - 1 9 7 9} \\
\text { Ortalama Deniz } \\
\text { Sicaklıkları }\left({ }^{\circ} \mathbf{C}\right)\end{array}$ & $\begin{array}{c}\mathbf{1 9 8 0 - 1 9 8 9} \\
\text { Ortalama Deniz } \\
\text { Sicaklıkları }\left({ }^{\circ} \mathrm{C}\right)\end{array}$ & $\begin{array}{c}\mathbf{1 9 9 0 - 1 9 9 9} \\
\text { Ortalama Deniz } \\
\text { Sicaklıkları }\left({ }^{\circ} \mathbf{C}\right)\end{array}$ & $\begin{array}{c}\mathbf{2 0 0 0 - 2 0 0 9} \\
\text { Ortalama Deniz } \\
\text { Sicaklıkları }\left({ }^{\circ} \mathbf{C}\right)\end{array}$ & $\begin{array}{c}\mathbf{2 0 1 0 - 2 0 1 9} \\
\text { Ortalama Deniz } \\
\text { Sicaklıkları }\left({ }^{\circ} \mathbf{C}\right)\end{array}$ \\
\hline Karadeniz & 15,1 & 14,8 & 14,7 & 15,5 & 16,3 \\
Marmara Denizi & 15,1 & 15 & 15,4 & 15,8 & 16,6 \\
Ege Denizi & 18,2 & 18,2 & 18,5 & 18,9 & 19,1 \\
Akdeniz & 21 & 21,1 & 21,2 & 21,7 & 22,2 \\
\hline
\end{tabular}

Dabanli vd. (2021) yapmış oldukları çalışma sonuçları da bu araştırmanın sonuçlarını destekler niteliktedir. İklim değişikliğinin Karadeniz, Marmara, Ege ve Akdeniz'deki deniz suyundaki eğilimini değerlendiren araştırmacılara göre kış mevsimi dışında tüm kıyı bölgelerinde deniz suyu sıcaklıkları artış eğilimindedir. Hem kış hem de yaz mevsimindeki sıcaklık değişimlerinin deniz yaşamı, balık populasyonu, turizm alışkanlığı, yağış rejimi ve kuraklık özelliğini değiştirmesinin beklendiğini bildirmişlerdir. Deniz suyu sıcaklığı ortalamalarındaki artışın özellikle 2010 yılından başlayarak 2019 yılına kadar devam ettiği görülmektedir. Uzun dönemli olarak deniz suyu sıcaklığ incelendiğinde; Karadeniz ortalama deniz suyu sıcaklığg $15,1{ }^{\circ} \mathrm{C}$ den (1970-1979 yılları arası) $16,3{ }^{\circ} \mathrm{C}$ 'ye $(2010-2019$ yılları arası) kadar yükselerek yaklaşık $1,2{ }^{\circ} \mathrm{C}$ derece 1 sınma göstermiştir. Akdeniz ortalama deniz suyu sıcaklığ 1 ise $21,0{ }^{\circ} \mathrm{C}$ den (1970-1979 yılları arası) $22,2{ }^{\circ} \mathrm{C}$ 'ye (2010-2019 yılları arası) kadar artış göstererek $1,2{ }^{\circ} \mathrm{C}$ derece 1 sı artış1 olduğu belirlenmiştir. Ege denizi ortalama deniz suyu sıcaklığı $18,2{ }^{\circ} \mathrm{C}$ den (1970-1979 yılları arası) $19,1^{\circ} \mathrm{C}$ 'ye $(2010$ 2019 yılları arası) kadar yükselmiş olup yaklaşık $0,9^{\circ} \mathrm{C}$ derece sıcaklık artışı söz konusudur. Marmara denizi ortalama deniz suyu sıcaklığ $15,1{ }^{\circ} \mathrm{C}$ den (1970-1979 yılları arası) $16,6{ }^{\circ} \mathrm{C}$ 'ye (2010-2019 yılları arası) kadar yükselerek yaklaşık $1,5{ }^{\circ} \mathrm{C}$ derece ısınma gerçekleşmiştir (MGM 2020). Türkiye kıyı sularında 1969-2014 yılları arası 22 istasyondan toplanan veri analizine dayandırılan başka bir çalışmada (Şisman 2021), tüm istasyonlar bazında Karadeniz ve Marmara denizlerindeki su sıcaklığındaki kısmi artış eğilimleri birbirine uyumlu iken, Akdeniz'de ölçülen deniz suyu sıcaklıklarının önemli derecede yükseliş trendinde olduğu belirtilmiştir. Şişman (2021) tarafından gerçekleştirilmiş olan trend analizi ile ortaya konulan periyodik bulgular bizim değerlendirmelerimizle doğrudan örtüşmektedir. 


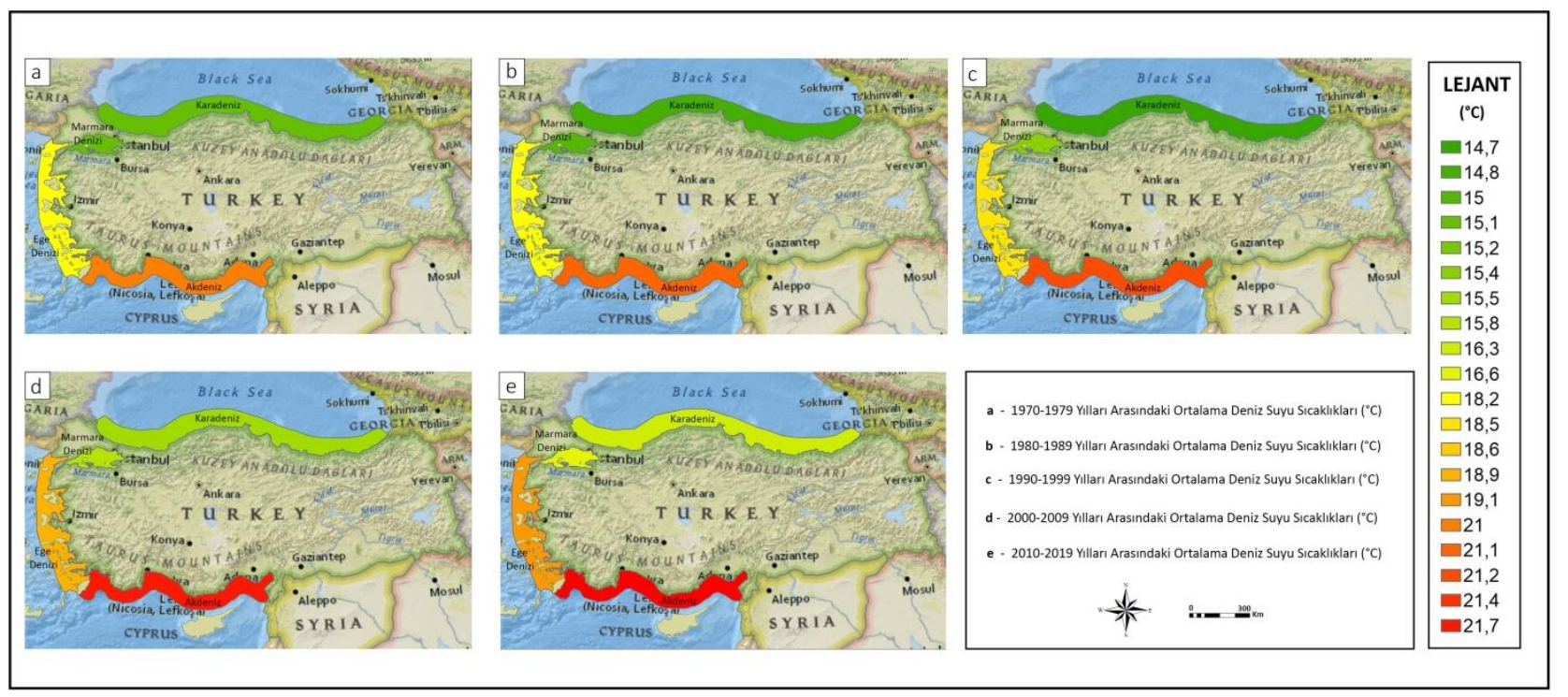

Şekil 10: Karadeniz, Akdeniz, Ege ve Marmara kıyıları deniz suyu sıcaklıkları haritası

\subsection{Deniz Suyu Sıcaklık Artışının Balık Ekosistemi Üzerindeki Etkileri}

Türkiye küresel ısınmanın etkisinde olup, yapılan çalışmalar özellikle sıcaklıkların artış eğiliminde olduğunu göstermektedir. Demircan vd. (2013) yapmış oldukları çalışmada, 1961-2010 ve 1981-2010 döneminde kış mevsimi hariç tüm mevsim ile yıllık serilerde anlamlı artış eğilimi belirlemişlerdir. Yine Demircan ve arkadaşlarının yapmış oldukları çalışmada, Türkiye'deki sıcaklık artışlarının 1997 yılından itibaren başladığını belirtmiştir (Demircan vd. 2015). Çalışmamızdaki veriler analiz edildiğinde ülkemizi çevreleyen Marmara, Karadeniz, Ege ve Akdeniz yüzey sularında iklim değişikliğinin etkisiyle belirgin deniz suyu sıcaklık artışı 90'lı yılların başından itibaren gözlemlenmektedir. Son 50 yıl içinde tüm denizlerimizde ortalama deniz suyu sıcaklığının en düşük $0,9^{\circ} \mathrm{C}$ ve en yüksek $1,5^{\circ} \mathrm{C}$ arttığı görülmüştür (Şekil 10). İklim değiş̧ikliği su kütlelerinin ısınmasına, deniz ortamlarının asitlenmesine yol açmaktadır. Deniz suyundaki sıcaklık artışı atmosferik yapıya da etki ederek yağış şekillerini değiştirmektedir (AÇA 2020). Bu durum sucul canlıların göç yollarını ve habitatlarını etkilemektedir. Deniz suyunun pH'ının azalmasına bağlı olarak su canlılarının beslenme ve gelişimi zarar görmektedir. Su üzerindeki bu baskı, balıkçılık ve yetiştiricilik faaliyetlerini de olumsuz olarak etkilemektedir (Diken 2020). Ayrıca Birleşmiş Milletler Gıda ve Tarım Örgütü; deniz suyu sıcaklığındaki artışların pek çok su ürünü popülasyonunun dağılımını ve balık avcıllı̆ının sürdürülebilirliğini etkilediğini, iklim değişikliğinin yetiştiricilik sektörü açısından da önemli bir tehdit oluşturduğunu belirtmektedir (FAO 2008a; 2008b). Özellikle sucul canlıların; suyun sıcaklığı, tuzluluk ve oksijen düzeyi gibi değişen çevresel koşullardan olumsuz yönde etkilenmesi, mutasyon ve ölüm oranının artması, hastalıklara karşı dirençsizlik, üreme bozuklukları gibi sorunlar nedeniyle insanların tüketebileceği gıda stokunun ve çeşitliliğinin azalmasına sebep olacaktır (Tirado vd. 2010; Fleming vd. 2006). Su ürünleri sucul ortamlardaki değişimlere karşı çok hassas olduğundan iklim değişikliğinin, yetiştiricilik ve balıkçılık sektörlerinde zararlara neden olması kaçınılmaz hale gelecektir (Mol ve Doğruyol 2012). Deniz suyu sıcaklığının 2 derece artması mercanların kitlesel ölümüne sebep olmuş (Öztürk vd. 2017), Akdeniz'de sıcaklığın $0.2 \mathrm{C}^{\circ}$ artması sonucu ise canlı sayısında artış görüldüğü ve daha önce Akdeniz'de görülmeyen yeni türlerin görülmeye başlandığı belirtilmiştir (Dalğın 2009). Yine iklim değişikliğinin bir sonucu olarak deniz suyu sıcaklığı arttıkça, zararlı alg patlamalarının meydana geldiği yıllık geçici periyot da uzayabilecektir (Tirado vd. 2010). Karadeniz'in ısınması sebebiyle yakın bir gelecekte Türkiye sularında hamsi görmek mümkün olmayabilecektir (Mol ve Doğruyol 2012). Sakarya Nehri ve İzmit Körfezi'nde görülen kitle halinde balık ölümlerinin su sıcaklığının artması, kirlilik, su seviyesinin yükselmesi, suda oksijen yetersizliği gibi iklim değişikliğgine bağlı faktörlerden önemli derecede etkilendiği düşünülmektedir. Ülkemiz balıkçılı̆̆ı için büyük önem taşıyan hamsi balıkları Kuzey Karadeniz sularının ısınması ve besin üretiminin artması ile birlikte daha ısınmış Güney Karadeniz yerine kuzey sularında kalmayı tercih edebilecekler ve ülkemiz kıyı sularına gelmeyebileceklerdir. Bu durum balık üretimimizin \% 80'ini sağlayan kaynağın ortadan kalkacağı anlamına geldiğinden ülke ekonomisi ve balıkçılarımız için çok ciddi bir sorun teşkil edecektir (Sağlam vd. 2008). Yapılan bu araştırma ile Karadeniz'deki 2000-2019 yılları arasındaki önemli sıcaklık artışları ortaya konulmuş olup, 2019 yılında gözlenen aşırı avlanma haricinde son on yıl içinde Türkiye kıyı sularında avlanan hamsi miktarında da önemli azalma eğilimi olduğu görülmektedir (Şekil 11). Küresel ısınma ve tropikalleşme etkisiyle Akdeniz ve Karadeniz'e gelen yabancı türlerin sayıları ve özellikleriyle ilgili ülkemizde bir veri bankası oluşturulduğu taktirde ekolojik gelişmelerle ilgili önümüzdeki dönemlerde daha doğru tahminlerin yapılabilmesi mümkün olacaktır (Kilıç 2008). 


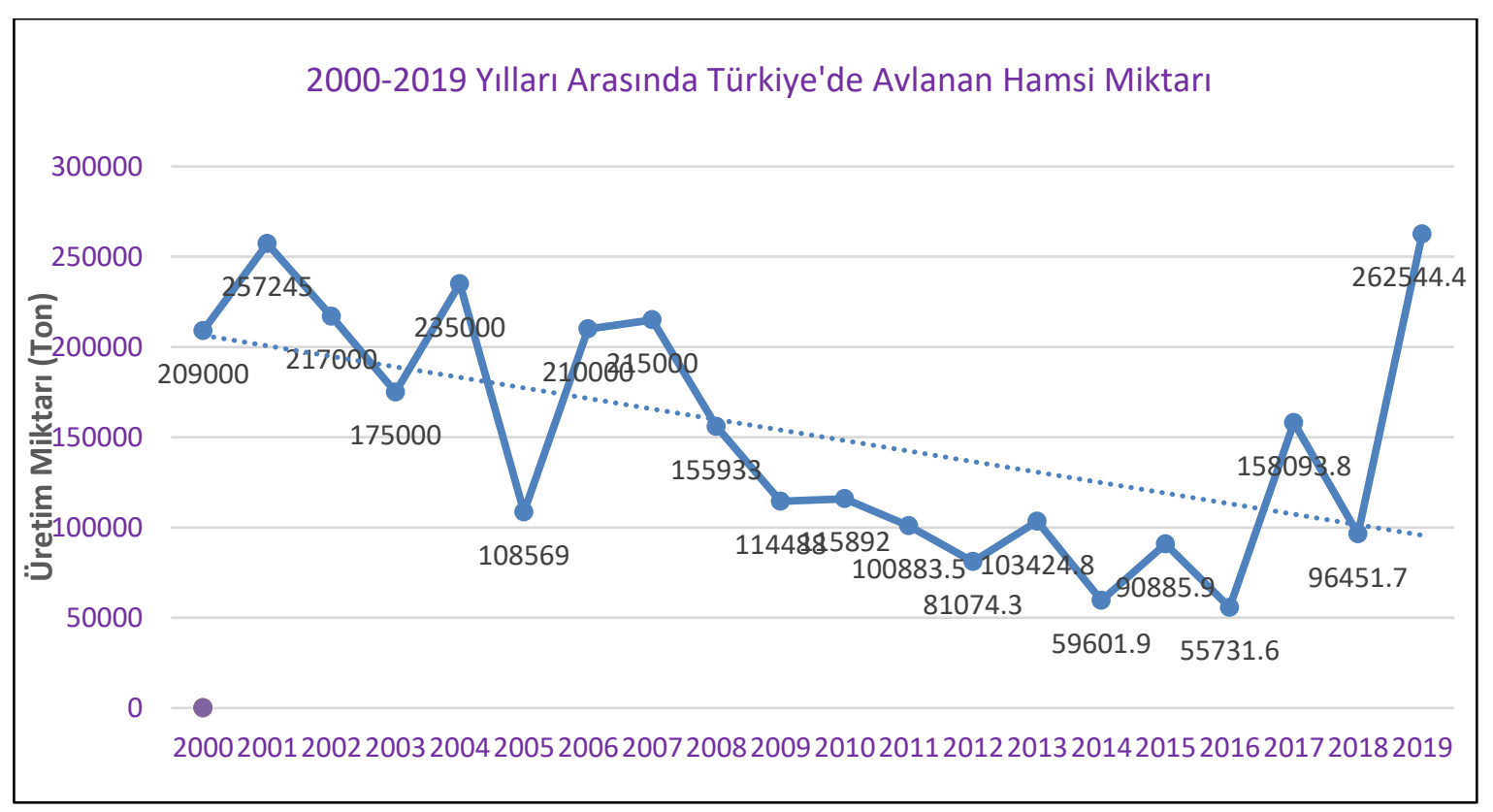

Şekil 11: 2000-2019 Yılları arasında Türkiye'de avlanan hamsi miktarı (TUIK 2020)

\section{Sonuç ve Öneriler}

Türkiye kıyıları deniz suyu sıcaklıklarının değerlendirildiği bu çalışma kapsamında; Son yıllarda dünyamızı etkileyen küresel ısınma, deniz suyu sıcaklıklarında artış eğilimi gösteren önemli bir faktör olarak karşımıza çıkmakta ve yaşanan bu durum deniz ekosistemindeki canlıları da belli bir ölçüde etkilemektedir. Yapılan araştırmada; Türkiye'yi çevreleyen Karadeniz, Akdeniz, Ege ve Marmara denizlerinin ortalama deniz suyu sıcaklıklarının uzun dönem trendine bakıldığında, yükselme eğiliminde olduğu belirlenmiştir. Meteoroloji Genel Müdürlüğünden temin edilen veriler ile gerçekleştirilen analizler sonrası, 2010-2019 yılları ortalama deniz suyu sıcaklarının 1970-1979'a göre önemli ölçüde farklılık gösterdiği, Karadeniz ve Akdeniz'de ortalama deniz suyu sıcaklıklarında $1,2{ }^{\circ} \mathrm{C}$, Ege denizinde $0,9{ }^{\circ} \mathrm{C}$ derece, Marmara denizinde ise $1,5^{\circ} \mathrm{C}$ dereceye ulaşan ortalama deniz suyu sıcaklığında yükseliş olduğu tespit edilmektedir. Deniz suyu sıcaklıklarındaki bu yükselişler, ülkemiz denizlerindeki biyoçeşitliliği etkilemesi kuvvetle muhtemel olup, hamsi gibi bazı balık türlerinde azalmaya ve avlanmada kısıtlamalara yol açabilecektir. Buda ülkemizde geçimini balıkçılıkla sağlayanlar için ekonomik kayıpların ortaya çıkması anlamına gelmekte olup, balıkçılık, su ürünleri yetiştiriciliği ve işleme sektörleriyle birlikte balıkçılık ekonomisinin olumsuz etkilenmesi anlamına gelmektedir. Öte yandan deniz suyu sıcaklıklarının artması, bazı egzotik türlere yaşama ortamı sağladığından istilacı türlerin Akdeniz, Ege, Marmara ve Karadeniz'e kadar ulaşabilmesini sağlayarak, endemik türler aleyhine ekolojik dengenin değişmesine sebep olabilecektir. Nitekim Akdeniz de görülen ve son zamanlarda Ege de sıklıkla görülmeye başlayan balon balığg, aslan balığı gibi türler kıyılarımızda hızla artmaya başlamıştır. İklim değişikliğine uyum çalışmaları kapsamında Tarım ve Orman Bakanlığı, endemik türler aleyhine ekolojik dengenin bozulmasını engelleme adına bu istilacı türlerin avlanması için her balon balığı kuyruğu başına 5 TL ödeme kararı almıştır. Yine 2021 yılında Bakanlık ilk kez belli bir süre hamsi balığı için avlanma yasağı uygulamasına imza atmıştır. Bu adımlar durumun ciddiyetini göstermektedir. Ülkemizdeki deniz suyu sıcaklıklarındaki yükselme eğilimlerinin son yıllara paralel düzeyde artış göstermesi durumunda, deniz ekosisteminin bu hızlı değişimden gelecekte önemli ölçüde etkilenmesi ve çok büyük sorunlarla karşılaşabilmesi aşikârdır. Deniz suyu sıcaklıklarındaki bu artışın, özellikle ilkbahar aylarında deniz salyası (müsilaj) oluşumlarını tetikleyerek deniz canlılarının yaşamlarını olumsuz yönde etkilemesi muhtemeldir. Su ürünleri potansiyelini korumak ve en iyi şekilde değerlendirebilmek için, iklim değişikliği uyum çalışmaları kapsamında bölgesel olarak kapsamlı proje çalışmalarına bir an önce başlanılması tavsiye edilmektedir. Ayrıca denizlerin ısınması ve asitlenmesi ile çevre üzerinde oluşan olası etkileri azaltabilmek ve belli bir ölçüde sınırlandırabilmek amacıyla iklim değişikliğinin olası etkilerini önlemeye yönelik planlamaların da şimdiden yapılmasının son derece önemli olduğu görülmektedir.

\section{Teşekkür}

Yazarlar, 1970-2019 yılları arasında ortalama deniz suyu sıcaklık verilerini bu makalede kullanabilmemize imkân sağlayan T.C. Tarım ve Orman Bakanlığı, Meteoroloji Genel Müdürlüğüne teşekkürlerini sunar. 


\section{Kaynaklar}

AÇA, (2020), Avrupa Çevre Ajansı, İklim Değişikliği ve Denizler, https://www.eea.europa.eu/tr/isaretler/isaretler-2015/makaleler /iklim-degisikligi-ve-denizler, [Erişim 15 Kasım 2020].

Baser V., Biyik C., (2019), Coastal and marine zone legislation within the concept of land management in Turkey, Survey Review, 51(369), 502-513.

Bengil F., Mavruk S., (2019), Warming in Turkish Seas: Comparative Multidecadal Assessment, Turkish Journal of Fisheries and Aquatic Sciences, 19, 51-57.

Bozkurt D., Sen O.L., (2011), Precipitation in the Anatolian Peninsula: sensitivity to increased SSTs in the surrounding seas, Climate Dynamics, 36(3-4), 711-726.

Çakıroğlu A.M., (2019), Karadeniz Türkiye kıyıları deniz suyu yüzey sıcaklıklarının meteorolojik yönden değerlendirilmesi, Yüksek Lisans Tezi, Recep Tayyip Erdoğan Üniversitesi, Rize.

Dabanli I., Şişman E., Güçlü Y.S., (2021), Climate change impacts on sea surface temperature (SST) trend around Turkey seashores, Acta Geophys. https://doi.org/10.1007/s11600-021-00544-2.

Dalğın S., (2009), Deniz suyu sicakllğı değişimlerinin gösteriminde en uygun enterpolasyon yönteminin belirlenmesi, 12. Türkiye Harita Bilimsel ve Teknik Kurultayı, 11-15 Mayıs, Ankara.

Demirbaş M., Aydın R., (2020), 21. Yüzyılın en büyük tehdidi: küresel iklim değişikliği, Ecological Life Sciences, 15(4), $163-179$.

Demircan M., Arabaci H., Bölük E., Akçakaya A., Ekici M., (2013), İklim normalleri: üç sıcaklık normalinin ilişkileri ve uzamsal dağılımları. III. Türkiye İklim Değişikliği Konferansı-TIKKDEK 2013, 3-5 Haziran, İTÜ Süleyman Demirel Kültür Merkezi, İstanbul.

Demircan M., Çiçek İ., Türkoğlu N., Ekici M., Arabacı H., (2015), Ortalama sıcaklıklardaki türdeşlik kırılmalarının iklim göstergeleriyle ilişkisi, VII. Uluslararası Katılımlı Atmosfer Bilimleri Sempozyumu, 28-30 Nisan, İstanbul Teknik Üniversitesi, İstanbul.

Diken G., (2020), Antropojenik iklim değişikliğinin balıkçılık ve su ürünleri üzerine etki ve yönetim stratejilerine genel bir bakış, Journal of Anatolian Environmental and Animal Sciences, 5(3), 295-303.

FAO, (2008a), Climate Change and Food Safety, http://www.fao.org/, [Erişim 12 Kasım 2020].

FAO, (2008b), Selected issues in fisheries and aquaculture (Part 2), The State of World Fisheries and Aquaculture. http://www.fao.org, [Erişim 10 Kasım 2020].

Fleming L., Broad K., Clement A., Dewailly E., Elmir S., Knap A., Pomponi S.A., Smith S., Solo Gabriele H., Walsh P., (2006), Oceans and human health: emerging public health risks in the marine environment, Marine Pollution Bulletin, 53(10-12), 545560 .

Girgin S., Akyürek S., Usul N., (2004), Türkiye için coğrafi bilgi sistemi tabanlı su kalitesi veri analiz sistemi geliştirilmesi. 3. Coğrafi Bilgi sistemleri Bilişim Günleri, 6-9 Ekim, İstanbul.

Hereher M.E., (2020), Assessment of climate change impacts on sea surface temperatures and sea level rise-The Arabian Gulf, Climate, 8(4), 50, doi: 10.3390/cli8040050.

Houghton E., (1996), Climate change 1995: The science of climate change: contribution of working group I to the second assessment report of the Intergovernmental Panel on Climate Change (Vol. 2): Cambridge University Press.

Kılıç A., (2008), Küresel ısınmanın su canlıları üzerine muhtemel etkileri, Kemaliye V. Geleneksel Su Ürünleri Platformu Sempozyum Kitab1, ss.8-11.

Kleypas J.A., Feely R.A., Fabry V.J., Langdon C., Sabine C.L., Robbins L.L., (2005), Impacts of ocean acidification on coral reefs and other marine calcifiers: a guide for future research, Paper presented at the Report of a workshop held, Vol. 18, No. 2005, ss. 20.

Kocataş A., (2005), Oseanoloji: deniz bilimlerine giriş ders kitabı: Ege Üniversitesi Su Ürünleri Kitaplar Serisi No:60, İzmir.

Li L., Cao R., Wei K., Wang W., Chen L., (2019), Adapting climate change challenge: A new vulnerability assessment framework from the global perspective, Journal of Cleaner Production, 217, 216-224.

MGM, (2020), Meteoroloji Genel Müdürlüğü. Türkiye'nin Deniz Suyu Sicaklıkları. https://www.mgm.gov.tr/veridegerlendirme/ilve-ilceler-istatistik.aspx?k=K. [Erişim 17 Kasım 2020].

MGM, (2021), Meteoroloji Genel Müdürlüğü. https://mgm.gov.tr/deniz/deniz-suyu-sicakligi.aspx, [Erişim 14 Ocak, 2021].

Mol S., Doğruyol H., (2012), The effect of climate change on seafood and their consumption, Journal of FisheriesSciences. com, 6(4), 341-356.

Öztürk B., Turan C., Özsoy E., Öztürk H., Güven K., Algan N., (2017), 2017 Yılı Türkiye denizleri raporu, Türk Deniz Araştırmaları Vakfi, İstanbul, 45ss.

Sağlam N.E., Düzgüneş E., Balık İ., (2008), Küresel isınma ve iklim değişikliği, Su Ürünleri Dergisi, 25(1), 89-94.

Savci S., Bağdatlı M., (2015), İçme sularındaki bazı ağır metallerin (Ni, Mn, Cu) CBS yardımıyla mekansal analizleri: Türkiye'nin Anadolu Bölgesinden Örnek Bir Çalışma, Uluslar. Hakemli Müh. ve Fen Bil. Der, 4, 65-78.

Şişman E., (2019), Ege ve Akdeniz klyılarında seçilen istasyonlarda deniz suyu sıcaklıkları için soğuma dönemi trend analizleri, Doğal Afetler ve Çevre Dergisi, 5(2), 291-304.

Şişman E., (2021), Power law characteristics of trend analysis in Turkey, Theor Appl Climatol, 143, 1529-1541.

Tirado M.C., Clarke R., Jaykus L., McQuatters-Gollop A., Frank J., (2010), Climate change and food safety: A review, Food Research International, 43(7), 1745-1765.

TUIK, (2020), Türkiye İstatistik Kurumu. https://www.tuik.gov.tr/, [Erişim 14 Ocak 2021]. 